\title{
Immunoelectron microscopic localization of $3 \beta$-hydroxysteroid dehydrogenase and type 5 $17 \beta$-hydroxysteroid dehydrogenase in the human prostate and mammary gland
}

\section{G Pelletier, V Luu-The, M El-Alfy, S Li and F Labrie}

Oncology and Molecular Endocrinology Research Center, Laval University Hospital (CHUL), Quebec, G1V 4G2, Canada

(Requests for offprints should be addressed to G Pelletier, Oncology and Molecular Endocrinology

Research Center, Laval University Hospital (CHUL), 2705, Laurier Boulevard, Quebec,

Quebec, G1V4G2, Canada; Email: georges.pelletier@crchul.ulaval.ca)

\begin{abstract}
The subcellular distribution of steroidogenic enzymes has so far been studied mostly in classical endocrine glands and in the placenta. In the peripheral intracrine organs which synthesize sex steroids there is no indication about the organelles which contain the enzymes involved in steroid biosynthesis. We have thus investigated the subcellular localization of two enzymes involved in the production of sex steroids, namely $3 \beta$ hydroxysteroid dehydrogenase (3 $\beta$-HSD) and type 5 17 $\beta$-hydroxysteroid dehydrogenase (17 $\beta$-HSD). Using specific antibodies to these enzymes, we conducted immunoelectron microscopic studies in two peripheral tissues, namely the human prostate and mammary gland. In the prostate, immunolabelling for both $3 \beta$-HSD and type $517 \beta$-HSD was detected in the basal cells of the tube-alveoli as well as in fibroblasts and endothelial cells lining the blood vessels. In all the labelled cell types, the gold particles were distributed throughout the cytoplasm. No obvious association with any specific
\end{abstract}

organelle could be observed, although some concentration of gold particles was occasionally found over bundles of microfilaments. In mammary gland sections immunolabelled for $3 \beta$-HSD or type 5 $17 \beta$-HSD localization, labelling was observed in the cytoplasm of the secretory epithelial cells in both the acini and terminal ducts. Immunolabelling was also found in the endothelial cells as well as in fibroblasts in stroma and blood vessels. The gold particles were not detected over any organelles, except with the occasional accumulation of gold particles over microfilaments. The present data on the localization of two steroidogenic enzymes leading to the synthesis of testosterone indicate that these enzymes are located not only in epithelial cells but also in stromal and endothelial cells in both tissues studied. The absence of any association of the enzymes with membrane-bound organelles appears as a common finding in the reactive cell types of two peripheral tissues.

Fournal of Molecular Endocrinology (2001) 26, 11-19

\section{INTRODUCTION}

The enzyme $3 \beta$-hydroxysteroid dehydrogenase (3ß-HSD) type 1 which catalyses the conversion of $\Delta 5-3 \beta$-hydroxysteroid precursors into $\Delta 4$ ketosteroids in all steroidogenic tissues has been purified from human placenta microsomes and mitochondria (Luu-The et al. 1989b, 1990). Molecular cloning studies then revealed two types of human 33-HSD (types 1 and 2) (Luu-The et al. 1989b, 1990, Lachance et al. 1990, 1991, Rhéaume et al. 1991). In addition to the gonadal tissues, $3 \beta$-HSD activity has been demonstrated in a variety of peripheral intracrine tissues, including the prostate and mammary gland (Lachance et al. 1990). At the light microscopic level, immunoreactive type $13 \beta$-HSD has been detected in the testis, ovary and adrenal cortex (Pelletier et al. 1992) and in the prostate (El-Alfy et al. 1999). In bovine and rat adrenal cortex, $3 \beta$-HSD activity has been shown to be associated with both the mitochondrial and microsomal fractions (Cherradi et al. 1993, 
1994, Sauer et al. 1994). By immunoelectron microscopy, 3 $\beta$-HSD immunoreactivity was found to be associated only with the smooth endoplasmic reticulum (Ishimura et al. 1988) in bovine adrenal cortex.

The enzyme $17 \beta$-hydroxysteroid dehydrogenase (17 $\beta$-HSD) controls the last step in the formation of all androgens and oestrogens. So far, six types of $17 \beta$-HSD have been characterized in the human (Jarabak et al. 1962, Peltoketo et al. 1988, Luu-The et al. 1989a, Wu et al. 1993, Geissler et al. 1994, Adamski et al. 1995, Lin et al. 1997, Nokelainen et al. 1998, Dufort et al. 1999, Krazeisen et al. 1999). Type $117 \beta-H S D$ is a soluble protein originally purified from human placenta (Jarabak et al. 1962), while types 2 and 3 17ß-HSD are microsomal enzymes cloned from human prostate and testis cDNA libraries respectively (Wu et al. 1993, Geissler et al. 1994). Type 4 17 $\beta$-HSD (Adamski et al. 1995) is a peroxisomal enzyme expressed in virtually all human tissues. The recently characterized human type 5 17 $\beta$-HSD (Lin et al. 1997, Dufort et al. 1999) is a soluble enzyme catalysing the reduction of 4-dione to testosterone in peripheral intracrine tissues. This enzyme plays a role in the formation of active androgens in peripheral tissues. Type $717 \beta$-HSD first cloned in a rat corpus luteum catalyses the transformation of oestrone $\left(\mathrm{OE}_{1}\right)$ to oestradiol $\left(\mathrm{OE}_{2}\right)$ (Nokelainen et al. 1998). Human type $717 \beta-\mathrm{HSD}$ is a $37 \mathrm{kDa}$ protein which has been found in the ovary, breast, placenta, testis, prostate and liver (Krazeisen et al. 1999).

Most of the data on the subcellular localization of steroidogenic enzymes have been obtained following subcellular fractionation studies (Pudney et al. 1985, Haniu et al. 1987, Luu-The et al. 1990, Cherradi et al. 1993, 1994, Sauer et al. 1994). In fact, the ultrastructural localization of steroidogenic enzymes obtained by immunoelectron microscopy has not so far been extensively investigated and the few reports on the subject are related to classical steroidogenic glands such as the testis, ovary and adrenal cortex (Ishimura et al. 1988, Shinzawa et al. 1988, Whitnall et al. 1993). We have recently developed antibodies against type $517 \beta$-HSD and shown by immunocytochemistry that this enzyme could be detected in reproductive organs, including the prostate, uterus and mammary gland (El-Alfy et al. 1999, Pelletier et al. 1999). So far, the ultrastructural localization of type $517 \beta$-HSD has not been reported. The purpose of the present study was to investigate the electron microscopic localization of two enzymes involved in sex steroid biosynthesis, $3 \beta$-HSD and type $517 \beta-\mathrm{HSD}$, in two intracrine human reproductive tissues, namely the prostate and mammary gland. As a positive control, the localization of $3 \beta$-HSD was also studied in the interstitial Leydig cells of the human testis.

\section{MATERIALS AND METHODS}

\section{Tissue preparation}

The mammary gland tissue specimens were obtained from pre-menopausal patients (25-40 years of age) who had breast reduction, while the prostatic specimens were obtained from patients (55-65 years of age) with benign prostatic hyperplasia undergoing transurethral prostatectomy. Testes were obtained from patients (50-60 years of age) who were castrated for prostate cancer treatment.

The specimens were fixed in 3\% paraformaldehyde and $1 \%$ glutaraldehyde in $0.2 \mathrm{M}$ phosphate buffer $(\mathrm{pH} 7 \cdot 4)$ within $15 \mathrm{~min}$ after they had been dissected out. After $12 \mathrm{~h}$, the tissues were post-fixed in 0.2 or $0.5 \%$ osmium tetroxide, embedded in Araldite and cut at $0.1 \mu \mathrm{m}$ with an ultramicrotome. For each organ under study, five separate tissue specimens were studied and the results were shown to be consistent.

\section{Immunocytochemistry}

The ultrathin sections were immunostained using the protein A-gold complex $(10 \mathrm{~nm}$; British Biocell International, Cardiff, UK), as described (Roth et al. 1978). The antiserum to $3 \beta$-HSD and type 5 $17 \beta$-HSD were both used at a 1:500 dilution. The $3 \beta$-HSD antiserum used was raised by immunizing rabbits with purified human placental type 1 3 $\beta$-HSD (Luu-The et al. 1989b, 1990). This antiserum has been widely used to localize $3 \beta$-HSD in several species, including the human (Pelletier et al. 1992). The antiserum to type $517 \beta$-HSD was raised by immunizing rabbits against a peptide sequence located at amino acid positions 297 to 320 of the human type $517 \beta$-HSD. The characteristics of the antiserum have been reported recently (El-Alfy et al. 1999, Pelletier et al. 1999). This antiserum has been successfully used for immunocytochemical localization in several human tissues, including the testis, prostate, breast, ovary and uterus (El-Alfy et al. 1999, Pelletier et al. 1999). Control experiments were performed by substituting non-immunized rabbit serum (1:500) or the antiserum (1:500) absorbed with an excess $\left(10^{-6} \mathrm{M}\right)$ of their respective antigen. 


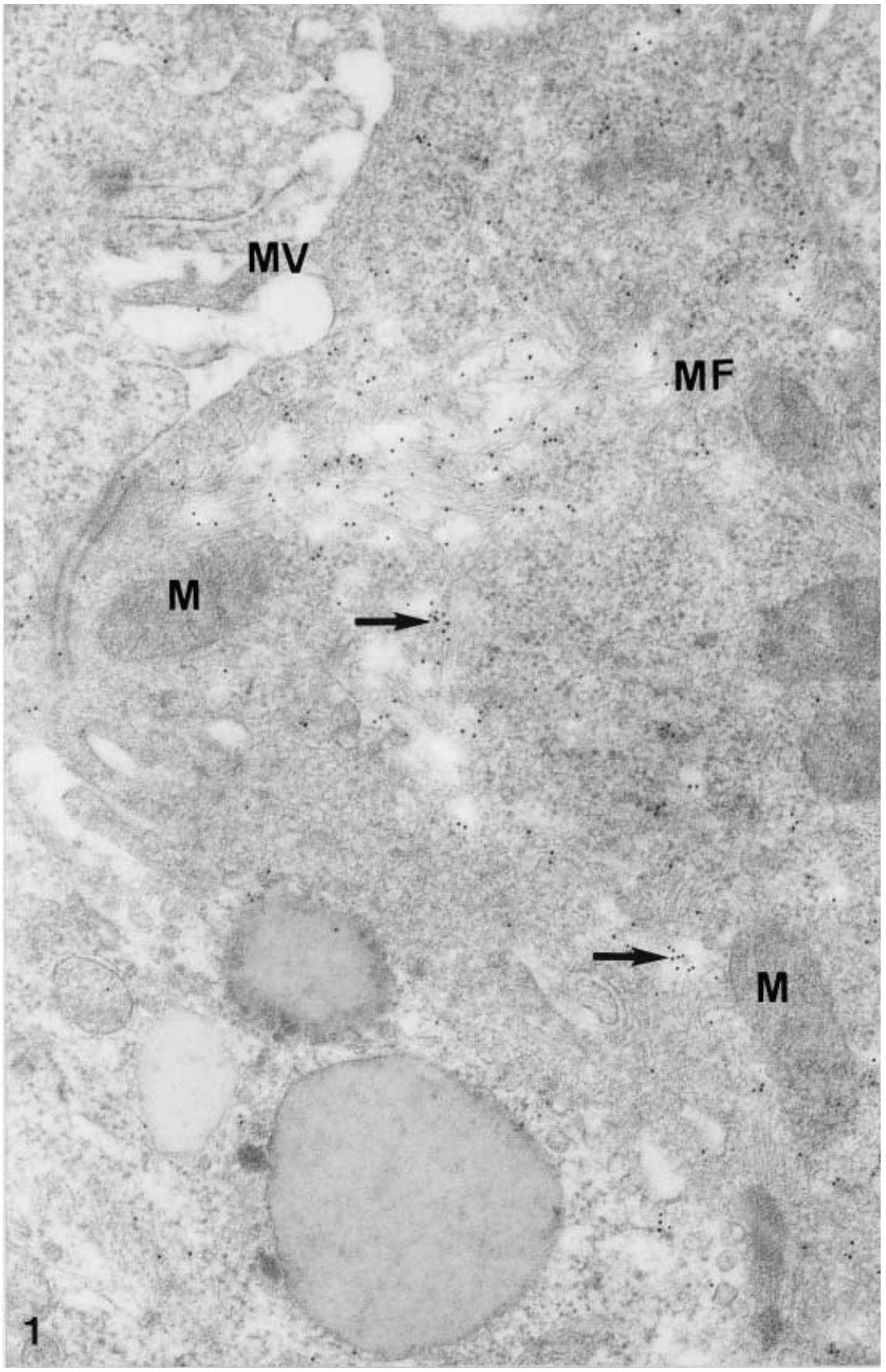

FIGURE 1. Part of an epithelial secretory cell of a mammary gland stained for $3 \beta$-HSD localization. Immunogold labelling $(\rightarrow)$ can be detected throughout the cytoplasm. Some gold particles are located over microfilament (MF) bundles. M: mitochondria; MV: microvilli projecting to the acinar lumen. $\times 64000$. 


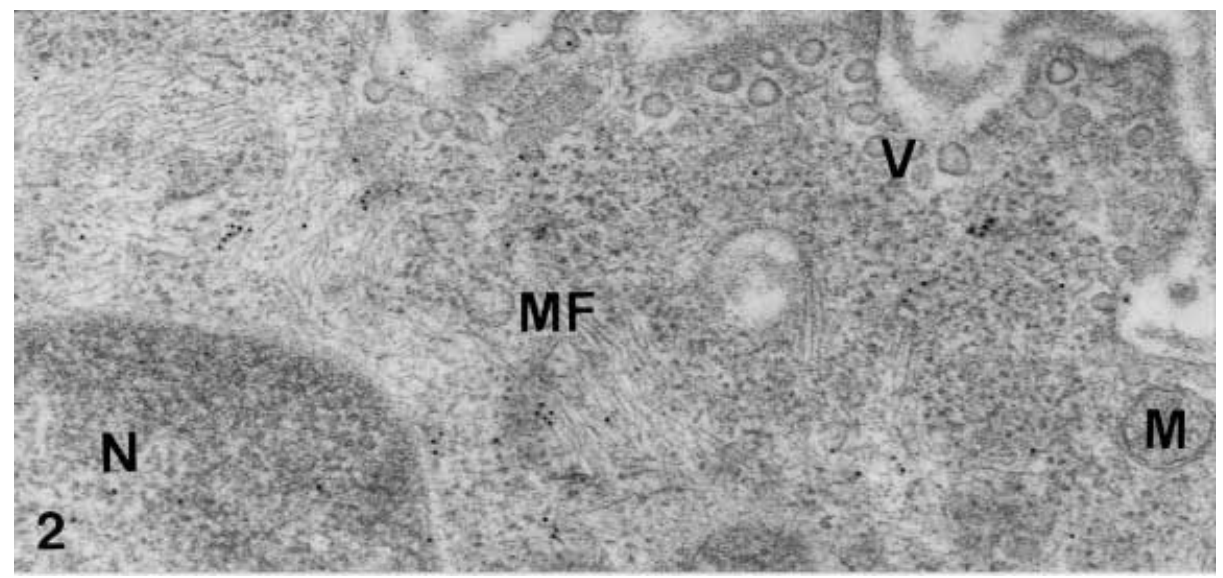

FIGURE 2. Part of a perivascular fibroblast of a mammary gland stained for type 5 $17 \beta$-HSD. Several gold particles are distributed throughout the cytoplasm.

Some particles are located over microfilament (MF) bundles. M: mitochondria; $\mathrm{V}$ : endocytotic vesicles; N: nucleus. $\times 64000$.

\section{RESULTS}

\section{Mammary gland}

The normal human mammary gland consists of ducts, acini and surrounding connective tissue. The epithelium lining the acini and ducts is composed of two layers: an inner columnal or cuboidal glandular epithelial layer and an outer discontinuous layer of myoepithelial cells. The myoepithelial cells are surrounded by a basement membrane. The epithelial cells contain free ribosomes, cisternae of rough endoplasmic reticulum as well as Golgi complexes which are not associated with secretory vesicles when the gland is resting. The epithelial cells show luminal microvilli. The contractile myoepithelial cells are characterized by abundant plasmalemmal vesicles and bundles of actin microfilaments. The cells also contain poorly developed cisternae of rough and smooth endoplasmic reticulum and small Golgi complexes.

In sections immunolabelled with $3 \beta$-HSD antibodies, the gold particles were localized throughout the cytoplasm of the epithelial cells in both the acini and terminal ducts. No organelles appeared to be specifically labelled (Fig. 1). A few gold particles were occasionally observed over bundles of microfilaments. No significant labelling could be detected over the myoepithelial cells. As previously observed at the light microscopic level (Pelletier et al. 1999), immunolabelling was found in the endothelial cells and fibroblasts lining blood vessels as well as in stromal fibroblasts. In these two cell types, immunolabelling did not generally appear to be associated with any specific organelle. As in epithelial cells, the association of gold particles with bundles of microfilaments was occasionally observed in the endothelial cells and fibroblasts. When the sections were immunolabelled for type 5 $17 \beta-H S D$, similar results were obtained, no labelling being associated with specific organelles in the three labelled cell types (Fig. 2).

\section{Prostate}

The stratified epithelium lining the tube-alveoli is divided into two layers: the basal layer made of low cuboidal cells which are separated from the stroma by a basement membrane and the layer of columnar secretory cells (luminal cells). The secretory cells possess luminal microvilli, well developed rough endoplasmic reticulum and numerous large secretory granules. The basal cells are devoid of any secretory granules.

In the tubulo-alveoli of human prostate specimens, immunolabelling for type $3 \beta$-HSD was almost exclusively observed in the basal cells, as recently found at the light microscopic level (El-Alfy et al. 1999, Pelletier et al. 1999). Immunolabelling was rather diffuse and did not appear to be restricted to specific organelles (Fig. 3).

As in the mammary gland, immunolabelling was also detected in the endothelial cells and fibroblasts of blood vessels as well as in the fibroblasts of stroma. The intracellular distribution of gold particles was rather diffuse throughout the cytoplasm. No obvious association with organelles was detected, except those bundles of microfilaments which occasionally appeared to be more labelled 


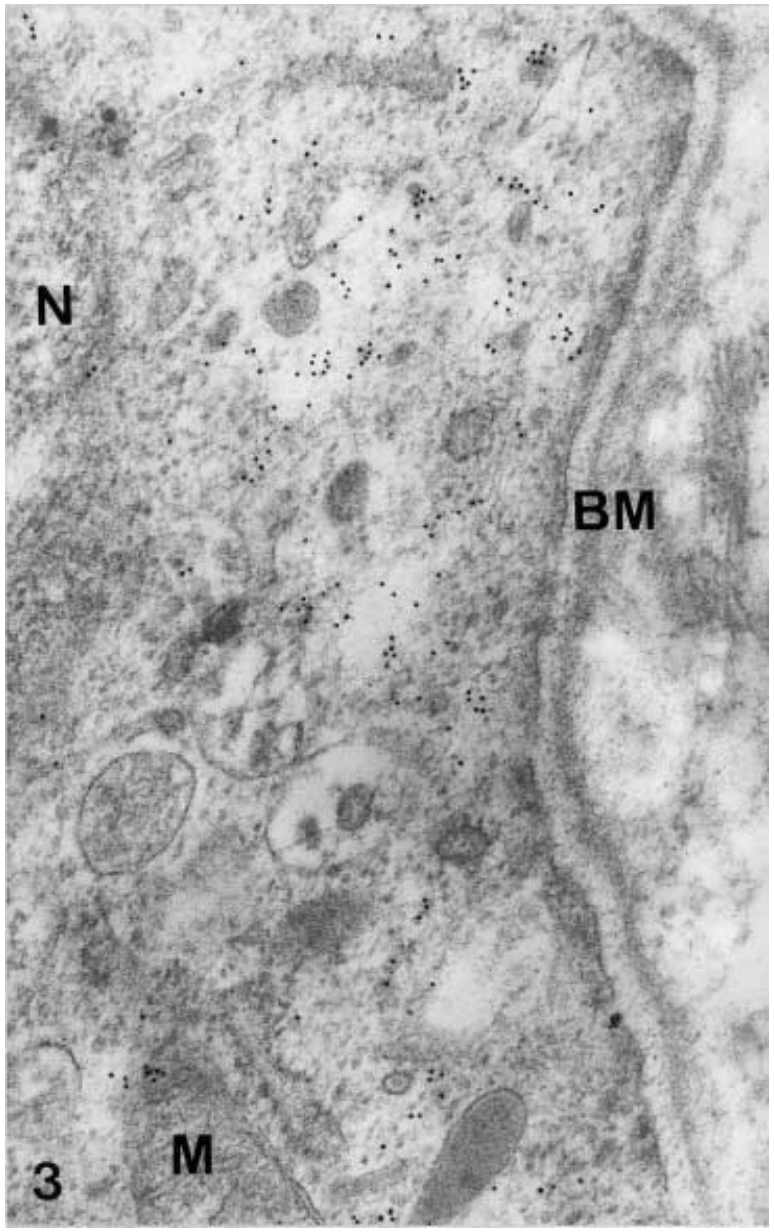

FIGURE 3. Part of a basal cell of the prostate epithelium stained for $3 \beta$-HSD localization. Numerous gold particles are overlying the cytoplasm. No association of gold particles with organelles is observed. M: mitochondria; $\mathrm{N}$ : nucleus; BM: basement membrane. $\times 64000$.

that the other cellular components. Very similar results were obtained with the anti-type 5 17 $\beta$-HSD (Fig. 4).

In the testis, as previously observed by light microscope studies (Pelletier et al. 1992), immunolabelling for the membrane-bound $3 \beta-H S D$ was restricted to the interstitial Leydig cells. The gold particles were predominantly detected over the numerous mitochondria and to a lesser extent over cisternae of the smooth endoplasmic reticulum (data not shown). When the antisera were immunoabsorbed with their respective antigens, no association of gold particles with any cell type could be observed. Only very few dispersed gold particles could be detected throughout the sections (Figs 5 and 6).

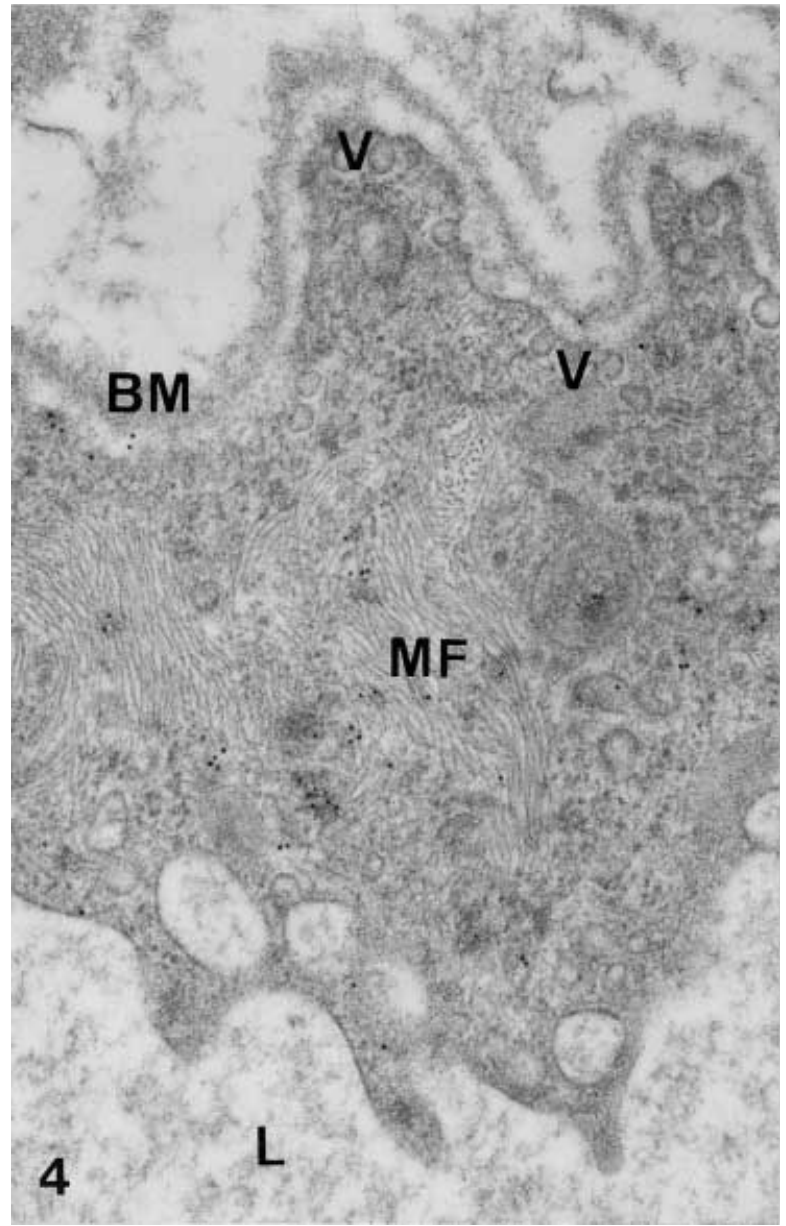

FIGURE 4. Prostate section stained for type $517 \beta$-HSD localization. Part of an endothelial cell of a capillary. Gold particles are distributed throughout the cytoplasm. V: endocytotic vesicles; MF: microfilaments; BM: basement membrane; L: capillary lumen. $\times 64000$.

\section{DISCUSSION}

In the prostate, the ultrastructural localization of $3 \beta$-HSD and type $517 \beta$-HSD immunoreactivity in basal cells of tube-alveoli, endothelial cells and fibroblasts confirm recent studies conducted at the light microscopic level (El-Alfy et al. 1999, Pelletier et al. 1999). Since type $517 \beta-$ HSD and $3 \beta-H S D$ are both expressed in basal cells, it may be suggested that testosterone synthesized in basal cells from circulating dehydroepiandrosterone (DHEA) reaches the luminal cells to be ultimately transformed into dihydrotestosterone (DHT) in the luminal cells by the action of $5 \alpha$-reductase (Levine et al. 1996, Pelletier et al. 1998). DHT would then exert its androgenic action in the luminal cells which contain 


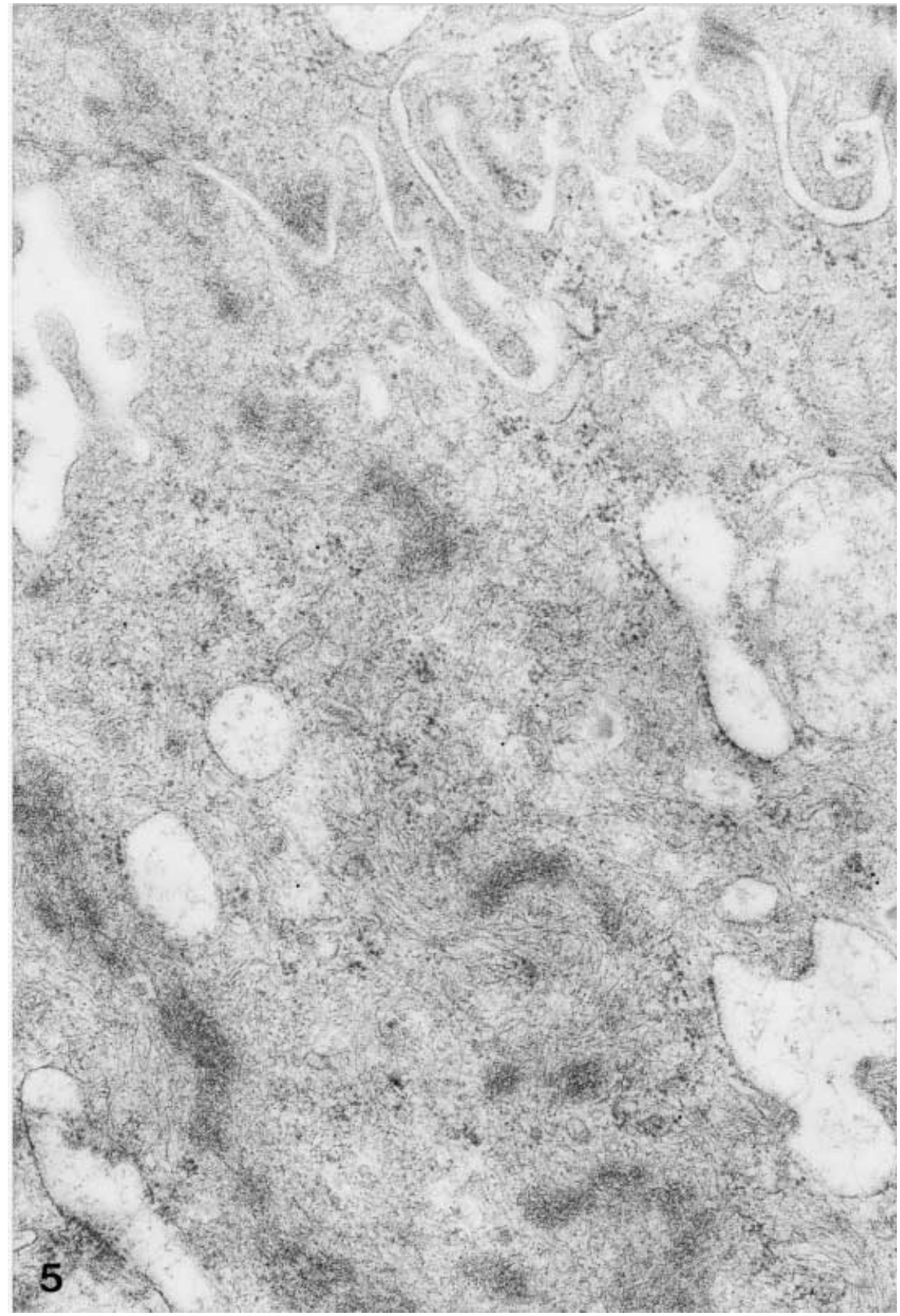

FIGURE 5. Control mammary gland section. Part of an epithelial secretory cell. Immunoabsorption of the antiserum to type $517 \beta$-HSD with the antigen has completely prevented any labelling. Only a very few dispersed gold particles can be detected. $\times 64000$.

androgen receptors (Ruizeveld de Winter et al. 1991, El-Alfy et al. 1999).

In the mammary gland, the present data demonstrate for the very first time the localization of $3 \beta$-HSD in the epithelial secretory cells in acini as well as in intralobular ducts. As observed in the prostate, the enzyme was also detected in stromal fibroblasts and in endothelial cells and fibroblasts of blood vessels. The present results also confirm previous data obtained at the light microscopic level indicating the presence of immunoreactive type 5 $17 \beta-H S D$ in the mammary cell types (Pelletier et al. 


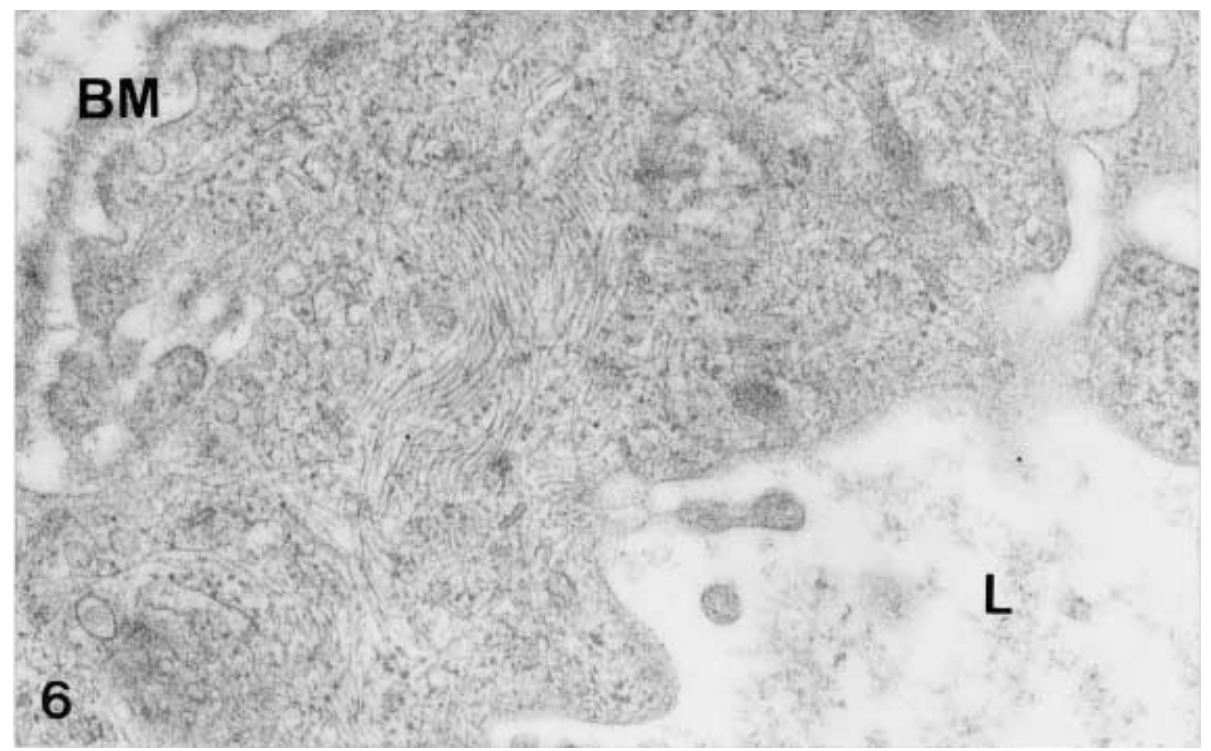

FIGURE 6. Control prostate section. Part of an endothelial cell of a capillary. Immunoabsorption of the antiserum to $3 \beta$-HSD with the purified human $3 \beta$-HSD has completely prevented any staining. Only a very few gold particles can be seen. BM: basement membrane; L: capillary lumen. $\times 64000$.

1999) which also contain $3 \beta$-HSD. It can therefore be suggested that these enzymes in the mammary gland are involved in testosterone biosynthesis following transformation of circulating DHEA into androstenedione. These cell types have also been shown to contain androgen receptors (Ruizeveld de Winter et al. 1991, Kimura et al. 1993). Therefore, it may be suggested that the intracellularly synthesized androgens directly influence the activity of the same cells (intracrine activity) (Labrie et al. 1988).

The subcellular distribution of different steroidogenic enzymes has been almost exclusively studied by subcellular fractionation experiments performed in steroid-secreting glands and placenta (Pudney et al. 1985, Haniu et al. 1987, Luu-The et al. 1989b, 1990, Rhéaume et al. 1991, Cherradi et al. 1993, 1994, Sauer et al. 1994). So far, the subcellular localization of steroidogenic enzymes in peripheral organs has not been reported. The present data obtained by immunoelectron microscopy clearly demonstrate that in two peripheral tissues, the prostate and mammary gland, $3 \beta$-HSD and type $517 \beta$-HSD are not confined to specific intracellular compartments in epithelial cells, fibroblasts of the stromal as well as endothelial cells and fibroblasts of blood vessels. The detection of $3 \beta-H S D$ in mitochondria and smooth endoplasmic reticulum of the Leydig cells indicate that this membrane-bound enzyme is associated with specific organelles in a steroid-secreting cell.
In steroid-secreting glands and in the placenta, $3 \beta$-HSD activity has been found to be associated with microsomal and mitochondrial fractions (Luu-The et al. 1989b, 1990, Rhéaume et al. 1991, Cherradi et al. 1993, 1994, Sauer et al. 1994). At the electron microscopic level, association of the enzyme with the smooth endoplasmic reticulum in the adrenal cortical cells has been confirmed (Ishimura et al. 1988). In peripheral organs where there is no typical steroid-secreting cell, the subcellular distribution of $3 \beta-H S D$ has not so far been reported. It is noteworthy that immunolabelling for $3 \beta-H S D$ was not associated with any organelles in the human prostate and mammary gland. The significance of the association of gold particles with microfilaments in many of the examined cells of the prostate and mammary gland remains to be clarified.

Type $517 \beta$-HSD is a soluble enzyme which has been purified from mouse liver (Deyashiki et al. 1995). In both the human prostate and mammary gland, type $517 \beta$-HSD immunoreactivity did not show any specific association with organelles, except with an occasional localization over bundles of microfilaments. In the rat central nervous system, it has been shown by immunoelectron microscopy that type $117 \beta-\mathrm{HSD}$, which is also a soluble enzyme (Jarabak et al. 1962), was exclusively located in astrocytes (Pelletier et al. 1995). In agreement with the present results, the gold particles were observed throughout the cytoplasm of 
glial cells without any specific association with organelles, such as smooth endoplasmic reticulum and mitochondria. In the mammary gland, it is noteworthy that the myoepithelial cells which contain a large number of microfilaments do not seem to contain any immunoreactivity for either enzyme.

A finding of interest was the localization of both $3 \beta$-HSD and type $517 \beta$-HSD in endothelial cells in both prostate and mammary gland tissues. This confirms previous observations at the light microscopic level indicating the presence of $3 \beta$ HSD and type $517 \beta-\mathrm{HSD}$ in endothelial cells in the prostate (El-Alfy et al. 1999, Pelletier et al. 1999 ) and that of type $517 \beta-H S D$ in endothelial cells in the mammary gland, ovary and uterus (Pelletier et al. 1999). On the other hand, these enzymes were not detected in several other tissues including testis (Pelletier et al. 1999), brain (Dupont et al. 1994), pituitary and liver (G Pelletier, V Luu-The, M El-Alfy, S Li \& F Labrie, unpublished data). It thus appears that the expression of the enzymes in endothelial cells is well restricted to some tissues.

Even though both $3 \beta$-HSD (Lachance et al. 1990) and type 5 17 $\beta$-HSD (Labrie et al. 1997) activities have been reported in prostate and mammary gland tissues, it is not possible on the basis of the present data to draw conclusions about the respective involvement of the different cell types in the synthesis of androgens from the precursor DHEA. Clearly, other studies involving quantitative approaches at the cellular level such as in situ hybridization are required for this information.

In summary, the present data on the ultrastructural localization of two steroidogenic enzymes which catalyse the synthesis of testosterone indicate that these enzymes are located not only in epithelial cells but also in stromal and endothelial cells in both the human prostate and mammary gland. In all these cell types there was no association of the enzymes with membranes or mitochondria. The occasional association of immunoreactive material with microfilaments remains to be clarified. Before generalizing the concept that in intracrine cells which do not possess the organelles found in cells specialized in endocrine steroidogenesis, the steroidogenic enzymes are not associated with any organelles, studies involving cell fractionation and immunoelectron microscopic studies on other tissues are required.

\section{REFERENCES}

Adamski J, Normand T, Leenders F, Monté D, Begue A, Stehelin D, Jungblut PW \& de Launoit Y 1995 Molecular cloning of a novel widely expressed human $80 \mathrm{kDa}$
$17 \beta$-hydroxysteroid dehydrogenase 4. Biochemical Fournal $311437-443$.

Cherradi N, Defaye G \& Chambaz EM 1993 Dual subcellular localization of the $3 \beta$-hydroxysteroid dehydrogenase isomerase: characterization of the mitochondrial enzyme in the bovine adrenal cortex. Fournal of Steroid Biochemistry and Molecular Biology 46 773-779.

Cherradi N, Defaye G \& Chambaz EM 1994 Characterization of the $3 \beta$-hydroxysteroid dehydrogenase activity associated with bovine adrenocortical mitochondria. Endocrinology 134 $1358-1364$.

Deyashiki Y, Ohshima K, Nakanishi M, Satao K, Matsuura K \& Hara A 1995 Molecular cloning and characterization of mouse estradiol $17 \beta$-dehydrogenase (A-specific), a member of the aldo-keto reductase family. Fournal of Biological Chemistry 270 10461-10467.

Dufort I, Rheault P, Huang XF, Soucy P \& Luu-The V 1999 Characteristics of a highly labile human type $517 \beta$ hydroxysteroid dehydrogenase. Endocrinology 140 1-7.

Dupont E, Simard J, Labrie F \& Pelletier G 1994 Localization of $3 \beta$-hydroxysteroid dehydrogenase in rat brain as studied by in situ hybridization. Molecular and Cellular Neurosciences 5 119-123.

El-Alfy M, Luu-The V, Huang XF, Berger L, Labrie F \& Pelletier G 1999 Localization of type $517 \beta$-hydroxysteroid dehydrogenase, $3 \beta$-hydroxysteroid dehydrogenase and androgen receptor in the human prostate by in situ hybridization and immunocytochemistry. Endocrinology 140 1481-1491.

Geissler WM, Davis DL, Wu L, Bradshaw KD, Patel S, Mendonca BB, Elliston KO, Wilson JD, Russell DW \& Andersson S 1994 Male pseudohermaphroditism caused by mutations of testicular 17 $\beta$-hydroxysteroid dehydrogenase 3 . Nature Genetics 7 34-39.

Haniu M, Yanagihashi K, Hall PF \& Shively JE 1987 Complete amino acid sequence of 21-hydroxylase cytochrome P-450 from porcine adrenal microsomes. Archives of Biochemistry and Biophysics 254 380-384.

Ishimura K, Yoshinaga-Hirabayashi T, Fujita H, Ishii-Ohba H, Inano H \& Tamaoki B 1988 Light and electron microscopic immunocytochemistry on the localization of $3 \beta$-hydroxysteroid dehydrogenase/isomerase in the bovine adrenal cortical cells. Histochemistry 89 35-39.

Jarabak J, Adams JA, Williams-Ashman HG \& Talalay P 1962 Purification of $117 \beta$-hydroxysteroid dehydrogenase of human placenta and studies on its transhydrogenase function. Fournal of Biological Chemistry 237 345-357.

Kimura F, Mizokami A, Oconuma T, Sasano H \& Nagura H 1993 Immunocytochemical localization of androgen receptor with polyclonal antibody in paraffin-embedded human tissues. Fournal of Histochemistry and Cytochemistry 4 671-678.

Krazeisen A, Breitling R, Imai K, Fritz S, Moller G \& Adamski J 1999 Determination of cDNA, gene structure and chromosomal localization of the novel human $17 \beta$ hydroxysteroid dehydrogenase type 7. FEBS Letters 460 373-379.

Labrie C, Bélanger A \& Labrie F 1988 Androgenic activity of dehydroepiandrosterone and androstenedione in the rat ventral prostate. Endocrinology 123 1412-1417.

Labrie F, Luu-The V, Lin SX, Labrie C, Simard J, Breton R \& Bélanger A 1997 The key role of $17 \beta$-hydroxysteroid dehydrogenases in sex steroid biology. Steroids 62 148-158.

Lachance Y, Luu-The V, Labrie C, Simard J, Dumont M, de Launoit Y, Guérin S, Leblanc G \& Labrie F 1990 Characterization of human $3 \beta$-hydroxysteroid dehydrogenase/ $\Delta 5-\Delta 4$ isomerase gene and its expression in mammalian cells. Fournal of Biological Chemistry 265 20469-20475. 
Lachance Y, Luu-The V, Verreault H, Dumont M, Rhéaume E, Leblanc G \& Labrie F 1991 Structure of the human type II $3 \beta$-hydroxysteroid dehydrogenase $/ \Delta 5-\Delta 4$ isomerase $(3 \beta$-HSD) gene: adrenal and gonadal specificity. DNA and Cell Biology 10 701-711.

Levine AC, Wang JP, Ren M, Eliashvili E, Russell DW \& Kirschenbaum A 1996 Immunohistochemical localization of steroid $5 \alpha$-reductase 2 in the human male fetal reproductive tract and adult prostate. Fournal of Clinical Endocrinology and Metabolism 81 384-389.

Lin HK, Jez JM, Schlegel BP, Peehl DM, Pachter JA \& Penning TM 1997 Expression and characterization of recombinant type $23 \alpha$-hydroxysteroid dehydrogenase (HSD) from human prostate: demonstration of bifunctional $3 \alpha / 17 \beta-H S D$ activity and cellular distribution. Molecular Endocrinology 11 1971-1984.

Luu-The V, Labrie C, Zhao HF, Couet J, Lachance Y, Simard J, Leblanc G, Côté J, Bérubé G, Gagné R \& Labrie F $1989 a$ Characterization of cDNAs for human estradiol 17 $\beta$-HSD and assignment of the gene to chromosome 17: evidence of two mRNA species with distinct $5^{\prime}$ termini in human placenta. Molecular Endocrinology 3 1301-1309.

Luu-The V, Lachance Y, Labrie C, Leblanc G, Thomas JL, Strickler RC \& Labrie F 1989 b Full length cDNA structure and deduced amino acid sequence of human $3 \beta$-hydroxy5-ene steroid dehydrogenase. Molecular Endocrinology 3 1310-1312.

Luu-The V, Takahashi M \& Labrie F 1990 Purification of microsomal and mitochondrial $3 \beta$-hydroxysteroid dehydrogenase $/ \Delta 3-\Delta 4$ isomerase from human placenta. In Steroid Formation, Degradation, and Action in Peripheral Tissue. Eds L Castagnetta, S d'Aquino, F Labrie \& HL Bradlow. Annals of the New York Academy of Sciences 595 386-388.

Nokelainen P, Peltoketo H, Vihko R \& Vihko P 1998 Expression cloning of a novel estrogenic mouse $17 \beta$ hydroxysteroid dehydrogenase/17-ketosteroid reductase (m17 HSD7), previously described as a prolactin receptorassociated protein (PRAP) in rat. Molecular Endocrinology 12 1048-1059.

Pelletier G, Dupont E, Simard J, Luu-The V, Bélanger A \& Labrie F 1992 Ontogeny and subcellular localization of $3 \beta$-hydroxysteroid dehydrogenase ( $3 \beta$-HSD) in the human and rat adrenal, ovary and testis. Fournal of Steroid Biochemistry and Molecular Biology 43 451-467.

Pelletier G, Luu-The V \& Labrie F 1995 Immunocytochemical localization of type I $17 \beta$-hydroxysteroid dehydrogenase in the rat brain. Brain Research 704 233-239.

Pelletier G, Luu-The V, Huang XF, Lapointe H \& Labrie F 1998 Localization by in situ hybridization of steroid $5 \alpha$-reductase isozyme gene expression in the human prostate and preputial skin. Fournal of Urology 160 577-582.

Pelletier G, Luu-The V, Têtu B \& Labrie F 1999 Immunocytochemical localization of type $517 \beta$ hydroxysteroid dehydrogenase in human reproductive tissues. Fournal of Histochemistry and Cytochemistry 47 731-737.

Peltoketo H, Isomaa V, Maentausta O \& Vihko R 1988 Complete amino acid sequence of human placental $17 \beta-$ hydroxysteroid dehydrogenase deduced from cDNA. FEBS Letters $23973-77$.

Pudney J, Canick JA, Clifford NM, Knapp JB \& Callar GV 1985 Location of enzymes of androgen and estrogen biosynthesis in the testis of the ground squirrel. Biology of Reproduction 33 971-980.

Rhéaume E, Lachance Y, Zhao HF, Breton N, Dumont M, de Launoit Y, Trudel C, Luu-The V, Simard J \& Labrie F 1991 Structure and expression of a new cDNA encoding the almost exclusive $3 \beta$-hydroxysteroid dehydrogenase $/ \Delta 5-\Delta 4$ isomerase in human adrenals and gonads. Molecular Endocrinology 5 1147-1157.

Roth J, Bendayan M \& Orci L 1978 Ultrastructural localization of intracellular antigens by the use of protein-A gold complex. Fournal of Histochemistry and Cytochemistry 26 1074-1081.

Ruizeveld de Winter JA, Trapman J, Vermey M, Mulder E, Zegers ND \& Van der Kwast TH 1991 Androgen receptor expression in human tissues: an immunohistochemical study. Fournal of Histochemistry and Cytochemistry 39 927-936.

Sauer LA, Chapman JC \& Dauchy R'T 1994 Topology of $3 \beta$-hydroxy-5-ene-steroid dehydrogenase $/ \Delta 5-\Delta 4$-isomerase in adrenal cortex mitochondria and microsomes. Endocrinology 134 751-759.

Shinzawa K, Ishibaski S, Murakoshi M, Watanabe K, Kominani S, Karvohara A \& Takemori S 1988 Relationship between zonal distribution of microsomal P4302 (P-450(17) alpha, lyase and P-450C21) and steroidogenic activities in guinea pig adrenal cortex. Fournal of Endocrinology 119 191-200.

Whitnall MH, Driscoll WJ, Lu YC \& Strott CA 1993 Estrogen and hydroxysteroid sulfatransferases in guinea pig adrenal cortex: cellular and subcellular distribution. Endocrinology $1332284-2291$.

Wu L, Einstein M, Geissler WM, Chan HK, Elliston KO \& Andersson S 1993 Expression cloning and characterization of human $17 \beta$-hydroxysteroid dehydrogenase type 2 , a microsomal enzyme possessing $20 \alpha$-hydroxysteroid dehydrogenase activity. Fournal of Biological Chemistry 268 12964-12969.

RECEIVED 25 May 2000 